\title{
Lance flies associated with sweet passion fruit and contributions to the knowledge on Lonchaeidae in Peru
}

\author{
Moscas-lança associadas ao maracujá-doce e \\ contribuições para o conhecimento de Lonchaeidae no Peru \\ Paolo Salvatore Salazar-Mendoza ${ }^{*}$ (D), Ivan Erick Peralta-Aragón² (D), \\ Maria Laura Misailidis ${ }^{3}$ (D) Ladislao Cesar Romero-Rivas ${ }^{2}$ (D), Pedro Carlos Strikis ${ }^{3}$
}

\begin{abstract}
The Lonchaeidae family comprises species that are considered of major economic importance due of their damage in several crops. In sweet passion fruit (Passiflora ligularis Juss), these flies cause high infestation in flower buds and fruits, however only a few basic studies about the species associated with the damage are available. Samples of flower buds and fruits were taken and McPhail trap baits with Torula yeast were placed in sweet passion fruit orchards in Oxapampa (Pasco, Peru) in 2015-2016. In addition, other hosts were collected in this period. We found Dasiops inedulis Steykal infesting the flower buds, while Dasiops frieseni Norrbom \& McAlpine infesting sweet passion fruits. Moreover, other Lonchaeidae-hosts interactions are related. Through Torula yeast baits, 14 species of lance flies were detected and high numbers of $D$. inedulis specimens were captured.
\end{abstract}

KEYWORDS: Dasiops inedulis; Dasiops frieseni; Torula yeast; hosts; Passiflora ligularis.
RESUMO: A família Lonchaeidae inclui espécies que são consideradas de grande importância econômica devido aos seus danos em diferentes cultivos. No maracujá-doce (Passiflora ligularis Juss), essas moscas causam altas infestaçóes em botóes florais e frutos, tendo ainda poucos estudos sobre as espécies associadas aos danos. Amostragem de botões florais e frutos foram realizadas e armadilhas McPhail com levedura de Torula foram colocadas em fazendas de maracujá em Oxapampa (Pasco, Peru) durante os anos de 2015 e 2016. Além disso, outros hospedeiros foram coletados nesse período. Nós encontramos Dasiops inedulis Steykal infestando botões florais e Dasiops frieseni Norrbom \& McAlpine em frutos de maracujá-doce. Além disso, outras interaçóes Lonchaeidae-hospedeiro são relacionadas. Mediante iscas de levedura de Torula, 14 espécies de Lonchaeidae foram detectadas e altos números de espécimes de $D$. inedulis foram capturados.

PALAVRAS-CHAVE: Dasiops inedulis; Dasiops frieseni; levedura de Torula; hospedeiros; Passiflora ligularis. 
Lance flies are insects belonging to the family Lonchaeidae (Diptera: Tephritoidea) that in Neotropical region are represented by the genera Dasiops Rondani, Neosilba McAlpine, and Lonchaea Fallén. Although this family has been considered of secondary importance (KORYTKOWSKI; OJEDA, 1971), in the last decades, various species are reported as of economic importance due to the damage produced in fruits, flowers and fruit buds (ADAIME et al., 2012; SALAZARMENDOZA; ROMERO-RIVAS, 2016; DOS SANTOS et al., 2017). Moreover, they are being considered as key pest in several crops (ARAÚJO; ZUCCHI, 2002; DELGADO et al., 2010; QUINTERO et al., 2012). Nevertheless, there are still little knowledge about the taxonomic position of the species associated with damages and about the existent trophic relationships, hindering biological and ecological studies with the aim to manage these flies.

Among the studies that sought to know the relationship between Passifloraceae and Lonchaeidae, STEYSKAL (1980) recorded for the first time flies of the genus Dasiops attacking species of Passifloraceae. Posteriorly, D. curubae was suggested to be used in the control of P. mollisima in Hawaii (CAUSTON et al., 2000). Henceforth, many species of this genus has been associated to damages in several Passifloraceae grown in South America.

Sweet passion fruit (Passiflora ligularis Juss) is a fruit original of Tropical America, cultivated in altitude of 1,700 2,500 masl (DELGADO et al., 2008). In the last decade, this crop has had a great growth in cultivated area turning Oxapampa city (Pasco region) into the first in this ranking in Peru (MENDIETA, 2015). Despite that growth in cultivated area, still few basic studies have been carried out about the species of Lonchaeidae associated with the damage in flower buds and fruits that frequently cause great economic losses with infestation levels up to $80-100 \%$ (CARRERO et al., 2013). Thus, the aim of this study was to extend the knowledge about Lonchaeidae species associated with sweet passion fruit.

Field trials were conducted at six locations within sweet passion fruit orchards ( $2-5$ years old and $1 \pm 2 \mathrm{ha}$ ): Lanturachi (10²3’09"S 7534'27"W, 1,862 masl), San Martín (10³5’46”S $75^{\circ} 29^{\prime} 03^{\prime \prime W}, 1,933$ masl), La Florida (10³6’30”S 7529’34”W, 1,982 masl), Torrebamba (10²2'26”S 75³4'43”W, 2,133 masl), Milpo (10'22'24”S 75³4'57”W, 2,140 masl), and Santa Bárbara $4\left(10^{\circ} 22^{\prime} 12^{\prime \prime} \mathrm{S} 75^{\circ} 35^{\prime} 10^{\prime \prime} \mathrm{W}, 2,227\right.$ masl) within the province of Oxapampa (Pasco, Peru), from September 2015 to August 2016. In each orchard, we collected 50 samples of flower buds (ten flower buds per sampling, totalizing 500 buds comprising $5.1 \mathrm{~kg}$ ) and 25 samples of immature fruits (five fruits per sampling, totalizing 125 buds comprising $9.35 \mathrm{~kg}$ ) of sweet passion fruit. Additionally, other hosts that grew in the orchard were collected: 10 samples of sweet lemon Citrus limon L. (five fruits per sampling, totalizing 50 comprising $4.5 \mathrm{~kg}$ ), 15 samples of rocoto pepper Capsicum pubescens R. \& P. (four fruits per sampling, totalizing 60 comprising $3.1 \mathrm{~kg}$ ), and 10 samples of stuffing cucumber Cyclanthera pedata Schrab (four fruits per sampling, totalizing 40 comprising $3.6 \mathrm{~kg}$ ). The samples collected were taken to the laboratory of the Universidad Nacional Daniel Alcides Carrión (UNDAC), where they were weighed and placed for $48-72 \mathrm{~h}$ in plastic cups (flower buds) or technopor boxes (fruits) to allow larval development and pupal stage formation. Subsequently, the fruits and flower buds were dissected, the larvae and pupae were transferred to other plastic cups kept at $22^{\circ} \mathrm{C}, 70 \% \mathrm{RH}$, and 12:12 L:D until adult emergence.

Furthermore, from May to August of 2016, one McPhail trap with Torula yeast as bait (5 pallets $/ 250 \mathrm{~mL}$ water) was placed in each orchard. Traps were placed in the same height of the fruits and floral buds. After seven days, the flies inside the traps were removed and the bait replaced. The adults were preserved in $70 \%$ ethanol for further identification. The numbers of Lonchaeidae trapped and those that emerged from the sampled were identified at species level using a stereomicroscope and biological microscope (MCALPINE; STEYSKAL, 1982; NORRBOM; McALPINE, 1997). Voucher specimens were deposited in the personal collection of P.C. Strikis and the entomological collection of the UNDAC filial Oxapampa.

Two species of genus Dasiops were associated to the damage to sweet passion fruit. Dasiops inedulis Steyskal (429 specimens) occasioned the ovarian rot and subsequent fall of flower buds and Dasiops frieseni Norrbom \& McAlpine (81 specimens) the wrinkling of immature fruits. The species $D$. inedulis is known as the bud flower fly because it feeds from tissues in the inside of the floral buds of various species of Passifloraceae (AGUIAR-MENEZES, 2004; LUNZ et al., 2006; STRIKIS et al., 2011; SANTOS et al., 2017) including sweet passion fruit in Colombia (AMAYA et al., 2009; CARRERO et al., 2013). Meanwhile, $D$. friesen $i$ was associated with damage in fruits of the same botanical family (AGUIAR-MENEZES, 2004; RAGA et al., 2015), however it is for the first time associated to $P$. ligularis.

Other bi-trophic relationships between Neosilba zadolicha McAlpine \& Steyskal (12) in sweet lemon, Neosilba certa (Walker) (7) in rocoto pepper, and Neosilba pseudopendula Korytkowski \& Ojeda (10) in stuffing cucumber were found. The genus Neosilba is the most studied of the Lonchaeidae and includes 40 species (GISLOTI et al., 2017). Neosilba zadolicha, which was considered a primary pest of commercial Citrus reticulata orchards in Paraíba, Northwest of Brazil (LOPES et al., 2008), is highlighted and is of great economic importance in South America due to the damage it causes in cultivated fruits and vegetables (NICÁCIO; UCHOA, 2011). Meanwhile, $N$. certa was associated with family host Myrtaceae, Annacardiaceae, Malpighiceae (SANTOS et al., 2017), Rubiaceae, Rosaceae (STRIKIS; PRADO, 2009), and Fabaceae (GISLOTI et al., 2017). N. pseudopendula was associated to Coffea arabica L. (SOUZA et al., 2005). GISLOTI et al. (2017) cite that Neosilba obtain food resources from a wide 
range of hosts belonging to 39 families, and this list includes Rutaceae, Solanaceae, and Cucurbitaceae, whose species were approached in our study. Nevertheless, very little is known about bi-trophic relations existing between Neosilba and hosts cultivated in Andean regions (> 1,800 masl).

McPhail traps baited with Torula yeast captured 8,209 species of Lonchaeidae containing the three genera related for Neotropical regions. Except for N. certa, this lure was efficient to catch species associated with damage in the different host and could be used as a tool for studies regarding the diversity of these species. Other species captured with Torula yeast were: Dasiops rugrifons Hennig 1948, Dasiops plaumanni McAlpine 1964, Dasiops luzestellae Castro, Korytkowski, Ebratt \& Brochero, 2013, Neosilba pendula (Bezzi 1919), Neosilba glaberrima (Wiedemann 1830), Neosilba plana Galeano-Olaya \& Canal 2012, Neosilba amphora Galeano-Olaya \& Canal, Neosilba sp, and Lonchaea sp.

KORYTKOWSKI; OJEDA (1971) did a review of the systematic of the species Lonchaeidae from Peru, mainly collected in McPhail traps in the Northern of the country between 1967-1970; since then, there have been no documented studies on these species in Peru. Nevertheless, the amount of lance flies species found in traps were different. In all weeks evaluated, D. inedulis was the most captured species (Fig. 1) with a mean of $87.9 \%$ of the total captures, $4.5 \%$ of $D$. frieseni, and $7.7 \%$ of other species this family, showing the potential of this substance as attractive to $D$. inedulis. IMBACHI et al. (2012) showed that the hydrolyzed proteins tested captured highest number of Lonchaeidae, but very few specimens of Dasiops saltans Townsend, the specie associated with damage to floral buds in yellow pitaya (Cactaceae). CARRERO et al. (2013) reported low capture of adult $D$. inedulis, with a maximum of 35 specimens captured with McPhail traps with bait made of hydrolyzed protein over a 15-day period.

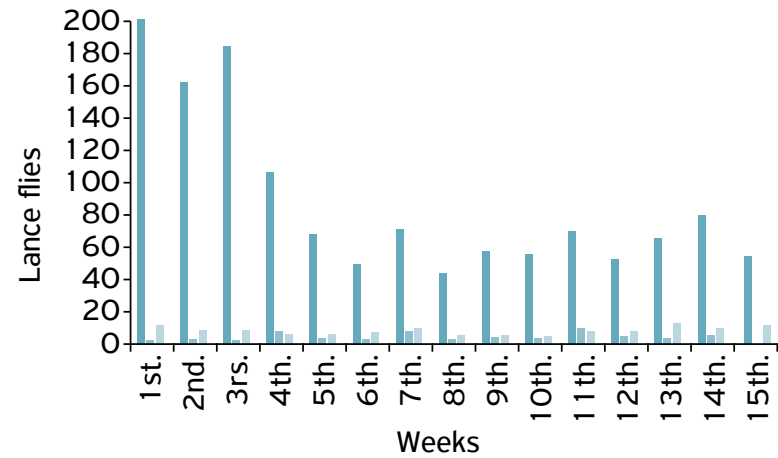

Dasiops inedulis Dasiops frieseni Other species

Figure 1. Mean of species of Lonchaeidae captured with McPhail traps using Torula yeast as bait in the six orchards between May-Aug 2016.

Meanwhile, SALAZAR-MENDOZA; ROMERO-RIVAS (2016) showed the efficacy of attractiveness of hydrolyzed proteins just to flies of genera Dasiops in sweet passion fruit. Currently, there are no baits available for $D$. inedulis, as there are lures based on protein hydrolysates employed to capture fruit flies (UCHOA, 2012). Thus, the use of Torula yeast as food bait may become an important tool in monitoring adult lance flies of some species of genus Dasiops, which have a great economic importance.

\section{ACKNOWLEDGMENTS}

The authors are grateful to National Agrarian Health Service (SENASA) for the logistical support, and the sweet passion fruit growers who allowed us access to their orchards.

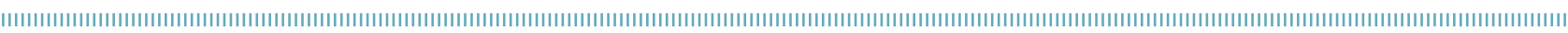
REFERENCES

ADAIME, R.; STRIKIS, P.C.; DE SOUZA-FILHO, M.F.; LIMA, C.R.; LASA, R. First report of Lonchaeidae (Diptera) infesting fruits of Byrsonima crassifolia in Brazil. Revista Colombiana de Entomología, v.38, n.2, p.363-364, 2012.

AGUIAR-MENEZES, E.L.; NASCIMENTO, R.J.; MENEZES, E.B. Diversity of fly species (Diptera: Tephritoidea) from Passiflora spp. and their hymenopterous parasitoids in two municipalities of the Southeastern Brazil. Neotropical Entomology, v.33, n.1, p.113-116, 2004. http://dx.doi.org/10.1590/S1519-566X2004000100020

AMAYA, O.S.; DEVIA, E.H.V.; SALAMANCA, J. Prueba de extractos vegetales para el control de Dasiops spp., en granadilla (Passiflora ligularis Juss.) en el Huila, Colombia. Corpoica Ciencia y Tecnología Agropecuaria, v.10, n.2, p.141-151, 2009.
ARAÚJO, E.L.; ZUCCHI, R.A. Hospedeiros e níveis de infestação de Neosilba pendula (Bezzi) (Diptera: Lonchaeidae) na região de Mossoró/Assu, RN. Arquivos do Instituto Biológico, v.69, n.2, p.91-94, 2002.

CARRERO, D.A.; MELO, D.; URIBE, S.; WYCKHUYS, K.A. Population dynamics of Dasiops inedulis (Diptera: Lonchaeidae) and its biotic and abiotic mortality factors in Colombian sweet passionfruit orchards. Journal of Pest Science, v.86, n.3, p.437-447, 2013. https://doi.org/10.1007/s10340-013-0487-9

CAUSTON, C.E.; MARKIN, G.P.; FRIESEN, R. Exploratory survey in Venezuela for biological control agents of Passiflora mollissima in Hawaii. Biological Control, v.18, n.2, p.1 10-119, 2000. https:// doi.org/10.1006/bcon.2000.0811 
DELGADO, A.; KONDO, T.; LÓPEZ, K.I.; QUINTERO, E.M.; MANRIQUE, M.B.; MEDINA, J.A. Biología y algunos datos morfológicos de la mosca del botón floral de la pitaya amarilla, Dasiops saltans (Townsend) (Diptera: Lonchaeidae) en el Valle del Cauca, Colombia. Boletín del Museo de Entomología de la Universidad del Valle, v. 11 , n.2, p.1-10, 2010.

DELGADO, S.R.; GARCIA, B.L.; AVENDAÑO, H.B. Riqueza de especies de pasifloras (Passifloraceae). Distribución geográfica en zonas altas de los Estados Andinos, Venezuela. Geoenseñanza, v. 13, n. 1, p.51-58, 2008.

DOS SANTOS, J.; BROGLIO, S.M.F.; DA COSTA, S.S.; DIAS-PINI, N.D.S.; STRIKIS, P.C. Record of lonchaeids (Diptera: Lonchaeidae) in municipalities of Alagoas State, Brazil. Revista Colombiana de Entomología, v.43, n.1, p.125-128, 2017. https://doi. org/10.25100/socolen.v43i 1.6660

GISLOTI, L.J.; UCHOA, M.A.; PRADO, A. New records of fruit trees as host for Neosilba species (Diptera, Lonchaeidae) in southeast Brazil. Biota Neotropica, v.17, n.1, p.201-213, 2017. http:// dx.doi.org/10.1590/1676-0611-bn-2016-0213

IMBACHI, K.; QUINTERO, E.; MANRIQUE, M.; KONDO, T. Evaluación de tres proteínas hidrolizadas para la captura de adultos de la mosca del botón floral de la pitaya amarilla, Dasiops saltans Townsend (Diptera: Lonchaeidae). Corpoica Ciencia y Tecnología Agropecuaria, v.13, n.2, p.159-166, 2012.

KORYTKOWSKI, C.A.; OJEDA, P.D. Revisión de las especies de la familia Lonchaeidae en el Perú (Diptera: Acalyptratae). Revista Peruana de Entomología, v.14, n.1, p.87-1 16, 1971.

LOPES, E.B.; BATISTA, J.L.; ALBUQUERQUE, I.C.; BRITO, C.H. Moscas frugívoras (Tephritidae e Lonchaeidae): Ocorrência em pomares comerciais de tangerina (Citrus reticulata Blanco) do município de matinhas, Estado da Paraíba. Acta Scientiarum Agronomy, v.30, Suppl., p.639-644, 2008. http://dx.doi.org/10.1590/ S1807-86212008000500006

LUNZ, A.M.; SOUZA, L.A.S.; LEMOS, W.P. Reconhecimento dos principais insetos praga do macujazeiro. Belém: Embrapa Amazônia Oriental, 2006. (Documentos 245). Avaliable from: https://ainfo. cnptia.embrapa.br/digital/bitstream/item/19015/1/Doc-245. pdf. Access on: Feb. 102019.

MENDIETA, P. Estiman que Perú exportará cerca de 36 mil kilos de granadilla este ano. 2015. In: AGENCIA AGRARIA DE NOTICIAS. Avaliable from: https://www.agroforum.pe/ agro-noticias/estiman-que-peru-exportara-cerca-de-36mil-kilos-de-granadilla-este-ano-7642/. Access on: Feb. 182019.

McALPINE, J.F.; STEYSKAL, G.C. A revision of Neosilba McAlpine with a key to world genera of Lonchaeidae (Diptera). Canadian Entomologist, v. 114 , n.2, p.105-137, 1982. https://doi. org/10.4039/Ent 1 14105-2
NICÁCIO, J.; UCHOA, M.A. Diversity of frugivorous flies (Diptera: Tephritidae and Lonchaeidae) and their relationship with host plants (Angiospermae) in environments of South Pantanal region, Brazil. Florida Entomologist, v.94, n.3, p.443-466, 2011 . https:// doi.org/10.1653/024.094.0309

NORRBOM, A.L.; McALPINE, J.F. A revision of the Neotropical species of Dasiops Rondani (Diptera: Lonchaeidae) attacking Passiflora (Passifloraceae). Memoirs of the Entomological Society of Washington, v.18, p.189-211, 1997.

QUINTERO, E.M.; LÓPEZ, I.C.; KONDO, T. Manejo integrado de plagas como estrategia para el control de la mosca del botón floral del maracuyá Dasiops inedulis Steyskal (Diptera: Lonchaeidae). Corpoica Ciencia y Tecnología Agropecuaria, v. 13, p.31-40, 2012.

RAGA, A.; DE SOUZA-FILHO, M.F.; STRIKIS, P.C.; MONTES, S.M.N.M. Lance fly (Diptera: Lonchaeidae) host plants in the State of São Paulo, Southeast Brazil. Entomotropica, v.30, n.7, p.57-68, 2015.

SALAZAR-MENDOZA, P.; ROMERO-RIVAS, C. Eficacia de trampas y atrayentes para moscas de la granadilla (Passiflora ligularis Juss.). Revista Peruana de Entomología, v.51, n.2, p.31-37, 2016.

SANTOS, O.O.; CASTELLANI, M.A.; BITTENCOURT M.A.L;; MOREIRA, A.A.; STRIKIS, P.C. Frugivorous Flies (Diptera: Lonchaeidae) Hosts in the State of Bahia, Brazil and registers of new bitrophic interactions. Brazilian Journal of Biology, v.78, n.3, p.591-592, 2017. http://dx.doi.org/10.1590/1519-6984.168836

SOUZA, S.A.; RESENDE, A.L.; STRIKIS, P.C.; COSTA, J.R.; RICCI, M.S.; AGUIAR-MENEZES, E.L. SOUZA, S.A, RESENDE, A.L.; STRIKIS, P.C.; COSTA, J.R.; RICCI, M.S.; AGUIAR-MENEZES, E.L. Infestação natural de moscas frugívoras (Diptera: Tephritoidea) em café arábica, sob cultivo orgânico arborizado e a pleno sol, em Valença, RJ. Neotropical Entomology, v.34, n.4, p.639-648, 2005. http:// dx.doi.org/10.1590/S1519-566X2005000400015

STEYSKAL, G.C. Two-winged flies of the genus Dasiops (Diptera: Lonchaeidae) attacking flowers or fruit of species of Passiflora (passion fruit, granadilla, curuba, etc.). Proceedings of the Entomological Society of Washington, v.82, n.2, p.166-170, 1980.

STRIKIS, P.C.; PRADO, A.P. Lonchaeidae associados a frutos de nêspera, Eryobotria japonica (Thunb.) Lindley (Rosaceae), com a descrição de uma espécie nova de Neosilba (Diptera: Tephritoidea). Arquivos do Instituto Biológico, v.76, n. 1, p.49-54, 2009.

STRIKIS, P.C.; DEUS, E.D.G.; DA SILVA, R.A.; PEREIRA, J.D.B.; DE JESUS, C.R.; MARSARO-JÚNIOR, A.L. Conhecimento sobre Lonchaeidae na Amazônia brasileira. In: SILVA, R.A.; LEMOS, W.P.; ZUCCHI, R.A. (Eds.). Moscas-das-frutas na Amazônia brasileira: diversidade, hospedeiros e inimigos naturais. Amapá: Embrapa, 2011.299 p. Chap. 13.

UCHOA, M.A. Fruit flies (Diptera: Tephritoidea): biology, host plants, natural enemies, and the implications to their natural control. In: LARRAMENDY, L.M.; SOLONESKI, S. Integrated pest management and pest control. Current and future tactics. Rijeka, Croatia: InTech, 2012. 668p. Chap. 12. 